\title{
VALUABLE \\ ANCIENT AND MODERN PAINTINGS
}

\author{
TUESDAY, MAY 9, 1916
}

IN THE GRAND BALLROOM OF THE PLAZA 
SMITHEONIAN
INETITUTION 


\section{CONDITIONS OF SALE}

1. Any bid which is merely a nominal or fractional advance may be rejected by the auctioneer, if, in his judgment, such bid would be likely to affect the sale injuriously.

2. The highest bidder shall be the buyer, and if any dispute arise between two or more bidders, the auctioneer shall either decide the same or put up for re-sale the lot so in dispute.

3. Payment shall be made of all or such part of the purchase money as may be required, and the names and addresses of the purchasers shall be given immediately on the sale of every lot, in default of which the lot so purchased shall be immediately put up again and re-sold.

Payment of that part of the purchase money not made at the time of sale shall be made within ten days thereafter, in default of which the undersigned may either continue to hold the lots at the risk of the purchaser and take such action as may be necessary for the enforcement of the sale, or may at public or private sale, and without other than this notice, re-sell the lots for the benefit of such purchaser, and the deficiency (if any) arising from such re-sale shall be a charge against such purchaser.

4. Delivery of any purchase will be made only upon payment of the total amount due for all purchases at the sale.

Deliveries will be made on sales days between the hours of 9 A. M. and 1 P. M., and on other days-except holidays-between the hours of $9 \mathrm{~A}$. M. and $5 \mathrm{P}$. M.

Delivery of any purchase will be made only at the American Art Galleries, or other place of sale, as the case may be, and only on presenting the bill of purchase.

Delivery may be made, at the discretion of the Association, of any purchase during the session of the sale at which it was sold.

5. Shipping, boxing or wrapping of purchases is a business in which the Association is in no wise engaged, and will not be performed by the Association for purchasers. The Association will, however, afford to purchasers every facility for employing at current and reasonable rates carriers and packers; doing so, however, without any assumption of responsibility on its part for the acts and charges of the parties engaged for such service.

6. Storage of any purchase shall be at the sole risk of the purchaser. Title passes upon the fall of the auctioneer's hammer, and thereafter, while the Association will exercise due caution in caring for and delivering such purchase, it will not hold itself responsible if such purchase be lost, stolen, damaged or destroyed. 
Storage charges will be made upon all purchases not removed within ten days from the date of the sale thereof.

7. Guarantee is not made either by the owner or the Association of the correctness of the description, genuineness or authenticity of any lot, and no sale will be set aside on account of any incorrectness, error of cataloguing, or any imperfection not noted. Every lot is on public exhibition one or more days prior to its sale, after which it is sold "as is" and without recourse.

The Association exercises great care to catalogue every lot correctly, and will give consideration to the opinion of any trustworthy expert to the effect that any lot has been incorrectly catalogued, and, in its judgment, may either sell the lot as catalogued or make mention of the opinion of such expert, who thereby would become responsible for such damage as might result were his opinion without proper foundation.

\section{AMERICAN ART ASSOCIATION, American Art Galleries, Madison Square South, New York City.}




\title{
FIRST EVENING'S SALE
}

\author{
TUESDAY, MAY 9, 1916
}

IN THE GRAND BALLROOM OF

THE PLAZA

Fifth Avenue, 58th to 59th Street

BEGINNING PROMPTLY AT 8.15 O'CLOCK

\section{ORDER OF SALE}

\section{1-Robert Henri, N.A.}

Coast of Monhegan, Maine

Panel: Height, 8 inches; length, 10 inches

Property of the Estate of the late Mrs. Gertrude Cowdin.

2-Arthur B. Davies

Pastoral

Canvas: Height, 8 inches; length, 121/2 inches

Property of the Estate of the late Mrs. Gertrude Cowdin.

\section{3-James Abbott McNeill Whistler} An Inn in an English Village Water Color: Height, 61/4 inches; width, 41/4 inches Property of Alexander Morten, Esq. 
4-Ralph Albert Blakelock, N.A. Landscape with Indians

Canvas: Height, 10 inches; width, 8 inches

Property of P. H. McMahon, Esq.

5-Thomas Wilmer Dewing, N.A. A Lady

Pastel: Height, 103/4 inches; width, 8 inches

Property of Alexander Morten, Esq.

6-Arthur B. Davies

Group of Four Children

Pastel: Height, 12 inches; width, 9 inches

Property of the Estate of the late Mrs. Gertrude Cowdin.

7-Robert ReID, N.A.

Head of a Young Woman

Panel: Height, 12 inches; width, 9 inches

Property of the Estate of the late Mrs. Gertrude Cowdin.

8-Ralph Albert Blakelock, N.A.

A Vase of Flowers

Panel: Height, 111/2 inches; width, 73/4 inches.

Property of P. H. McMahon, Esq.

9-Ralph Albert Blakelock, N.A. Carnations and Zinnias

Panel: Height, 111/2 inches; width, 73/4 inches

Property of P. H. McMahon, Esq. 


\section{0-Henry Ward Ranger, N.A.}

\section{Gathering Wood}

Water color: Height, 16 inches; width, 11 inches

Property of Charles Beers, Esq.

11-George Herbert McCord, A.N.A.

Off the Coast of Holland

Canvas: Height, 12 inches; length, 16 inches

Property of P. H. McMahon, Esq.

12-Guillaume Seignac

In a Dilemma

Panel: Height, 131/2 inches; width, 10 inches

Property of P. H. McMahon, Esq.

13-Karl Breydel

The Battle

Height, 111/2 inches; length, 18 inches

Property of Mrs. Benjamin Thaw.

14-W. F. Witherington, R.A.

English Landscape

Canvas: Height, 12 inches; length, 16 inches

By order of an Executrix.

15-Nicolas Berghem (Attributed to)

Cattle and Landscape

Canvas: Height, 161/2 inches; length, 19 inches

Property of Mrs. Benjamin Thaw. 
16-Adriaen Van de Velde

\section{Landscape and Cattle}

Panel: Height, 141/2 inches; length, 193/4 inches

By order of an Executrix.

17-Arthur B. Davies

Visions of Glory

Canvas: Height, 101/2 inches; length, 15 $\frac{1}{4}$ inches.

Property of the Estate of the late Mrs. Gertrude Cowdin.

18-William Langson Lathrop, N.A. Landscape

Canvas: Height, 141/2 inches; length, 18 inches

Property of Alexander Morten, Esq.

19-Robert Reid, N.A.

Landscape

Panel: Height, 121/2 inches; length, 16 inches.

Property of the Estate of the late Mrs. Gertrude Cowdin.

20-John H. Twachtman

Landscape

Canvas: Height, 123/4 inches; length, 181/2 inches

Property of the Estate of the late Mrs. Gertrude Cowdin. 


\section{1-Childe Hassam, N.A.}

\section{A Flower Garden}

Water color: Height, 191/2 inches; width, 131/2 inches

Property of Alexander Morten, Esq.

22-Juliet Thompson

Head of a Young Woman

Pastel: Height, 191/2 inches; width, 151/2 inches

Property of Alexander Morten, Esq.

23-Charlotte Buell Coman, A.N.A.

Landscape

Canvas: Height, 161/2 inches; length, 19 inches

Property of Alexander Morten, Esq.

24-Eastman Johnson, N.A. The Finishing Touch

Millboard: Height, 201/2 inches; width, 161/2 inches

Property of P. H. McMahon, Esq.

\section{5-Theodore Robinson}

\section{An Ancient House: Winter}

Canvas: Height, 18 inches; length, 22 inches

Property of the Estate of the late Mrs. Gertrude Cowdin. 
26-Frederick W. Kost, N.A.

Duck Shooting

Canvas: Height, 16 inches; length, 24 inches

Property of P. H. McMahon, Esq.

27-William Merritt Post, A.N.A.

The Lowland Meadows

Canvas: Height, 16 inches; length, 26 inches

Property of P. H. McMahon, Esq.

28-Edward Gay, N.A.

The Fisherman's Home, Eastchester, Creek

Canvas: Height, 18 inches; length, 24 inches

Property of P. H. McMahon, Esq.

29-Frank Knox Morton Rehn, N.A.

The Gulf Stream

Canvas: Height, 16 inches; length, 28 inches

Property of P. H. McMahon, Esq.

30-Theodore Robinson

The White Barn

Canvas: Height, 151/2 inches; length, 251/2 inches

Property of the Estate of the late Mrs. Gertrude Cowdin. 
31-Early Spanish School Saint in Attitude of Prayeyr Canvas: Height, 19 inches; width, 14 inches Property of Mrs. Benjamin Thaw.

\section{2-Bernard Van Orley Madonna and Child}

Panel: Height, 19 inches; width, 14 inches Property of Mrs. Benjamin Thaw.

\section{3-Early Flemish School Portrait of a Gentleman} Panel: Height, 201/2 inches; width, 16 inches Property of Mrs. Benjamin Thaw.

\section{4-Federigo Zucchero}

Portrait of Robert Devereux, Earl of Essex

Panel: Height, 223/4 inches; width, 17 inches

By order of an Executrix.

35-Sir Edwin Landseer, R.A.

Odin (Companion picture to No. 36)

Canvas: Height, 17 inches; length, 21 inches

Property of a Private Collector. 
36-Sir Edwin Landseer, R.A.

Hafed (Companion picture to No.

35)

Canvas: Height, 17 inches; length, 203/4 inches

Property of a Private Collector.

37-Louis Coignard

The Ox Team

Canvas: Height, 15 inches; length, 22 inches

Property of a Private Collector.

38-Jean Baptiste Greuze

The Suppliant (In contemporary frame

Canvas: Height, 20 inches; width, 16 inches

By order of an Executrix.

39-Federigo Zucchero

Fernando Cortez

Panel: Height, 223/4 inches; width, 171/4 inches

By order of an Executrix.

40-Louis Jimenez

Resting

Canvas: Height, 20 inches; length, 241/2 inches

Property of a Private Collector. 


\section{1-John Crome (Old Crome)}

\section{Landscape in Norfolk}

Canvas: Height, 251/2 inches; width, 221/2 inches

By order of an Executrix.

\section{2-Sir Peter Lely}

\section{Princess Mary of Holland}

Canvas: Height, 25 inches; roidth, 183/4 inches

By order of an Executrix.

43-Nicolas de LargiLlinère

Princess Clémentine Sobieski (Mother of Prince Charles Stuart, the Pretender)

Canvas: Height, 24 inches; width, 20 inches

Property of a Private Collector.

\section{4-Early Dutch School Landscape}

Canvas: Height, 21 inches; length, 29 inches

Property of Mrs. Benjamin Thaw.

\section{5-Eugene Higgins}

\section{Beside the Cradle}

Painted on copper: Height, 20 inches; width, 151/2 inches

Property of Alexander Morten, Esq. 
46-Sir Joshua Reynolds, P.R.A.

Portrait of Dr. Samuel Arnold

Canvas: Height, 29 inches; ridth, 241/2 inches

By order of an Executrix.

47-Clara Taggart McChesney Still Life

Water color: Height, 16 inches; length, 221/4 inches

Property of Alexander Morten, Esq.

48-Childe Hassam, N.A. The Woodchoppers

Canvas: Height, 18 inches; length, 22 inches

Property of Alexander Morten, Esq.

49-John H. Twachtman The Deserted Wharf

Canvas: 20 inches square

Property of Alexander Morten, Esq.

50-Theodore Robinson

Farmhouse and Rick

Canvas: Height, 151/2 inches; length, 251/2 inches

Property of the Estate of the late Mrs. Gertrude Cowdin. 
O51-John H. Twachtman

Autumn

Canvas: Height, 25 inches; width, 16 inches

Property of Alexander Morten, Esq.

52-Thomas Wilmer Dewing, N.A.

Portrait of Margaret Anglin

Silverpoint: Height, 213/4 inches; roidth, 191/2 inches

Property of Alexander Morten, Esq.

53-Bruce Crane, N.A.

Golden Afternoon

Canvas: Height, 18 inches; length, 24 inches

Property of Mrs. Joseph M. Carlisle.

54-Childe Hassam, N.A.

\section{A Winter Day}

Height, 191/2 inches; length, 25 inches

Property of the Estate of the late Mrs. Gertrude Cowdin.

55-Charlotte Buell Coman, A.N.A.

\section{Landscape}

Canvas: Height, 25 inches; ridth, 191/2 inches

Property of Alexander Morten, Esq. 
56-William Keith

Forest Interior

Canvas: Height, 20 inches; length, 24 inches

Property of a New York Collector.

57-J. Wells Champney, A.N.A.

Marie Antoinette (After the portrait

by Madame Vigée Le Brun, in

the gallery at Versailles)

Pastel: Height, 27 inches; width, 211/2 inches

Property of Alexander Morten, Esq.

58-Middleton Manigault

The Sky Rocket

Canvas: Height, 20 inches; length, 24 inches

Property of Alexander Morten, Esq.

59-Benjamin West, P.R.A. The Return from the Promised Land

Panel: Height, 21 inches; length, 29 inches

By order of an Executrix.

60-LÉON RICHET

Retour de Pêche

Canvas: Height, 22 inches; length, 32 inches

Property of a Private Collector. 
61-George Morland

The Wreckers

Canvas: Height, 25 inches; length, 30 inches

By order of an Executrix.

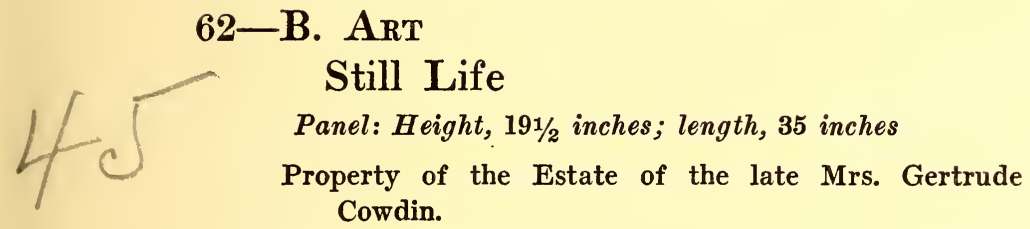

63-Émile Auguste Pinchart

Chrysalis

Canvas: Height, 32 inches; width, 23 $\frac{1}{4}$ inches

Property of a Private Collector.

64-Pierre Marie Beyle

Une Partie de Dames

Canvas: Height, 37 inches; width, 26 inches

Property of a Private Collector.

65-Early Spanish School

$$
\text { A Lady with Branch of Palm }
$$

Canvas: Height, 361/2 inches; width, 30 inches

Property of Mrs. Benjamin Thaw. 
66-Early English School The Light from Heaven

Canvas: Height, 36 inches; width, 28 inches

Property of Mrs. Benjamin Thaw.

67-Sir Peter Lely

Child and Dog

Canvas: Height, 30 inches; width, 241/2 inches

Property of a Private Collector.

68-Eighteenth Century French School A Lady with a Harp

Canvas: Height, 371/2 inches; width, 281/2 inches

Property of Mrs. Benjamin Thaw.

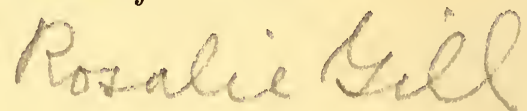

69-B. AnT

\section{Arab with a Knife}

Canvas: Height, 35\%/4 inches; roidth, 24 inches

Property of the Estate of the late Mrs. Gertrude Cowdin.

70-Arthur B. Davies

Triptych

Central panel, canvas: Height, 17 inches; length, 22 inches Side panels, each: Height, 121/2 inches; width, 51/2 inches

Property of the Estate of the late Mrs. Gertrude Cowdin. 


\section{1-Robert Reid, N.A.}

\section{Girl and Green Shutter}

Canvas: Height, 30 inches; width, 25 inches

Property of Alexander Morten, Esq.

72-Eugene Higgins

The Chain Gang

Water color: Height, 241/2 inches; length, 34 inches

Property of Alexander Morten, Esq.

73-John H. Twachtman The Beach at Squam

Canvas: Height, 25 inches; length, 30 inches

Property of the Estate of the late Mrs. Gertrude Cowdin.

74-Bruce Crane, N.A.

The Brandywine Valley

Canvas: Height, 22 inches; length, 30 inches

Property of P. H. McMahon, Esq.

75-Hugh Bolton Jones, N.A. Summertime

Canvas: Height, 22 inches; length, 36 inches

Property of Mrs. Joseph M. Carlisle. 
76-Leonard Ochtman, N.A.

The Harvest Field

Canvas: Height, 24 inches; length, 36 inches

Property of P. H. McMahon, Esq.

77-John H. Twachtman

House on Rocks Above Pool and Stream

Canvas: 30 inches square

Property of the Estate of the late Mrs. Gertrude Cowdin.

78-John H. Twachtman

The White Bridge

Canvas: 30 inches square

Property of Alexander Morten, Esq.

79-Bruce Crane, N.A.

In the Mohawk Valley

Canvas: Height, 36 inches; width, 30 inches

Property of P. H. McMahon, Esq.

80-Augustus Vincent Tack

Eve Weeping

Canvas: Height, 36 inches; width, 28 inches

Property of Alexander Morten, Esq. 
81-Wliliam Merritt Chase, N.A. Still Life

Canvas: Height, 281/2 inches; length, 391/2 inches

Property of the Estate of the late Mrs. Gertrude Cowdin.

82-George Elmer Browne

A Domestic Task

Canvas: Height, 311/2 inches; length, 381/2 inches

Property of Alexander Morten, Esq.

83-George H. Bogert, A.N.A. Moonlight

Canvas: Height, 28 inches; length, 40 inches

Property of Mrs. Joseph M. Carlisle.

84-Jonas Lie, A.N.A.

The Fog

Canvas: Height, 35 inches; length, 42 inches

Property of Alexander Morten, Esq.

85-John H. Twachtman

In the Garden

Canvas: Height, 26 inches; length, 69 inches

Property of the Estate of the late Mrs. Gertrude Cowdin. 
86-George Henry Smillie, N.A.

Marblehead Neck, Massachusetts

Canvas: Height, 30 inches; length, 45 inches

Property of P. H. McMahon, Esq.

87-AlLAN RAMSAY

Portrait of a Lord Chief Justice

Canvas: Height, 40 inches; width, 34 inches

Property of Mrs. Benjamin Thaw.

88-George Romney (Attributed to)

The Sisters

Canvas: Height, 43 inches; width, 28 inches

Property of Mrs. Benjamin Thaw.

89-Carlo Maratti

Claudius Caesar

Canvas: Height, 78 inches; width, 58 inches

Property of Mrs. Benjamin Thaw.

90-José Villegas Cordero The Page

Canvas: Height, 81 inches; width, 39 inches

Property of a Private Collector. 


\section{1-Juan Carreño de Miranda}

\section{Christianity Vanquishing Paganism}

Canvas: Height, 89 inches; roidth, 67 inches

Property of Mrs. Benjamin Thaw.

92-Hilaire Germain Edgar Degas

Collection of Twenty Lithographs

1. Young woman, nude; 2. Nude figure; 3. Young woman, nude; 4. Young woman, danseuse, tying buskin; 5. Blanchisseuse; 6. Danseuse et morceaux; $\%$ Young woman, nude; 8. Danseuse in exercises; 9. The Bath; 10. Study of drapery; 11. Danseuses à la barre; 12. Danseuse at attention; 13. Danseuse levant la jambe; 14. Study of drapery; 15. Jockeys, mounted; 16. Danseuse in exercises; 17. Seated figure of young woman; 18. Female figure in costume of about 1870; 19. Half-length portrait of a lady; 20. Study of drapery.

Property of the Estate of the late Mrs. Gertrude Cowdin.

American Art Association, Managers.

Thomas E. Kirby, Auctioneer. 

COMPOSITION, PRESSWORK

AND BINDING BY

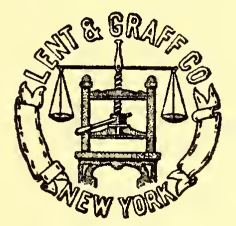




SMITHSONIAN INSTITUTION LIBRARIES
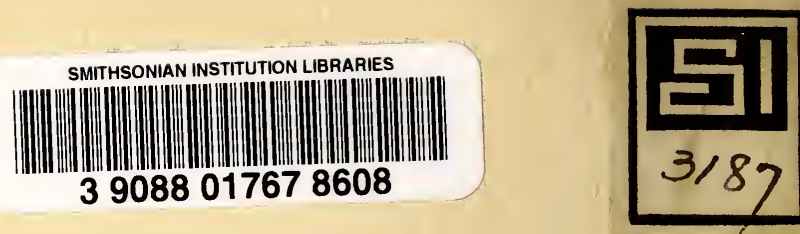